Review Article

\title{
A Dangerous and Endangered Species
}

\author{
Andrew Hague* \\ Professor of Advanced Medicine, United Kingdom
}

\begin{abstract}
Humans were formed when their brains changed. They gained technical skills and lost communication skills. The result was violence far in excess of all other creatures and damage has been inflicted on everything from our planet to us. At last, mass communication by technology may compensate for inherent inadequacy if we learn to manage ourselves.
\end{abstract}

Keywords: Addiction, Violence, Evolution, Compulsive behavior, War, Dictators, Environment, Cancer, Opioid, Cell sonic

\section{When did it all go wrong?}

It has always been wrong. There were other hominids, Denisovans, Neanderthals and so on and we did a bit of breeding with them and then killed them. Why live happily with others when you can kill them? We always kill. We kill each other, animals, plants and our planet. It's what we do. We are humans. We are very successful.

\section{Brains use electrical signals}

They are very sensitive to electric forces most of which are not man-made. There is the 7.83 hertz Schuman Resonance radiating to earth from the ionosphere and there are thunder storms. The Schuman Resonance existed before any form of life appeared. All life developed under its influence and without it, life as we know it is abnormal, maybe impossible. Thunder storms release high voltage static electricity from the atmosphere. Lightning descends from the sky with millions of volts shorting to ground. Fires can be started and a direct hit is lethal. To be in the vicinity of a lightning strike is to be in the electrical field of a force that can affect our bodies, especially the brain. That is how Homo Sapiens evolved; that's our species. We call ourselves humans and the word "humanity" is used to imply a spirit of comradeship amongst all humans. How much of that spirit is kindness and how much is violent is the question?

\section{There were various hominids}

Two legged, two armed creatures with hands and a head equipped with two eyes and two ears around a brain controlling the body. The family tree as detected by DNA analysis shows Homo Erectus millions of years ago leading to Homo Heidelbergens is hundreds of thousands of years ago with Homo Sapiens appearing about a hundred thousand years ago alongside Homo Denis ova and Homo Neanderthalensis who became extinct but not before some breeding with Homo Sapiens took place. It is believed that from Homo Denis ova came the genes enabling tolerance of cold and high altitude as found today in Tibet and Homo Neanderthalensis contributed genes with distinctive skin and hair and improved immune response (Figure 1).

For lightning to have affected the brain, it must have affected the brains of all creatures and still does because lightning happens continuously and always will. Homo Sapiens were not the only animals affected and are not the only creatures with capable brains. Many animals have skills far better than humans. Birds and some animals and fish have navigational skills by which they traverse the globe seasonally with amazing accuracy. Smell and hearing are far

\begin{tabular}{|l|l|}
\hline Quick Response Code: & *Corresponding author: Andrew Hague, Professor of advanced medicine, President of Cell \\
Sonic, United Kingdom & Published: 12 November, 2020 \\
& Received: 23 October, 2020 \\
& Citation: Andrew Hague. A Dangerous and Endangered Species. Glob Scient Res Env Sci. \\
\hline
\end{tabular}


better in many animals than in humans. The advantage, if it is an advantage, is the hominid structure with only two legs for travel on the ground leaving two arms with hands for holding tools. Those with four or more legs could only grasp with their mouth which is less dexterous than a hand with fingers.

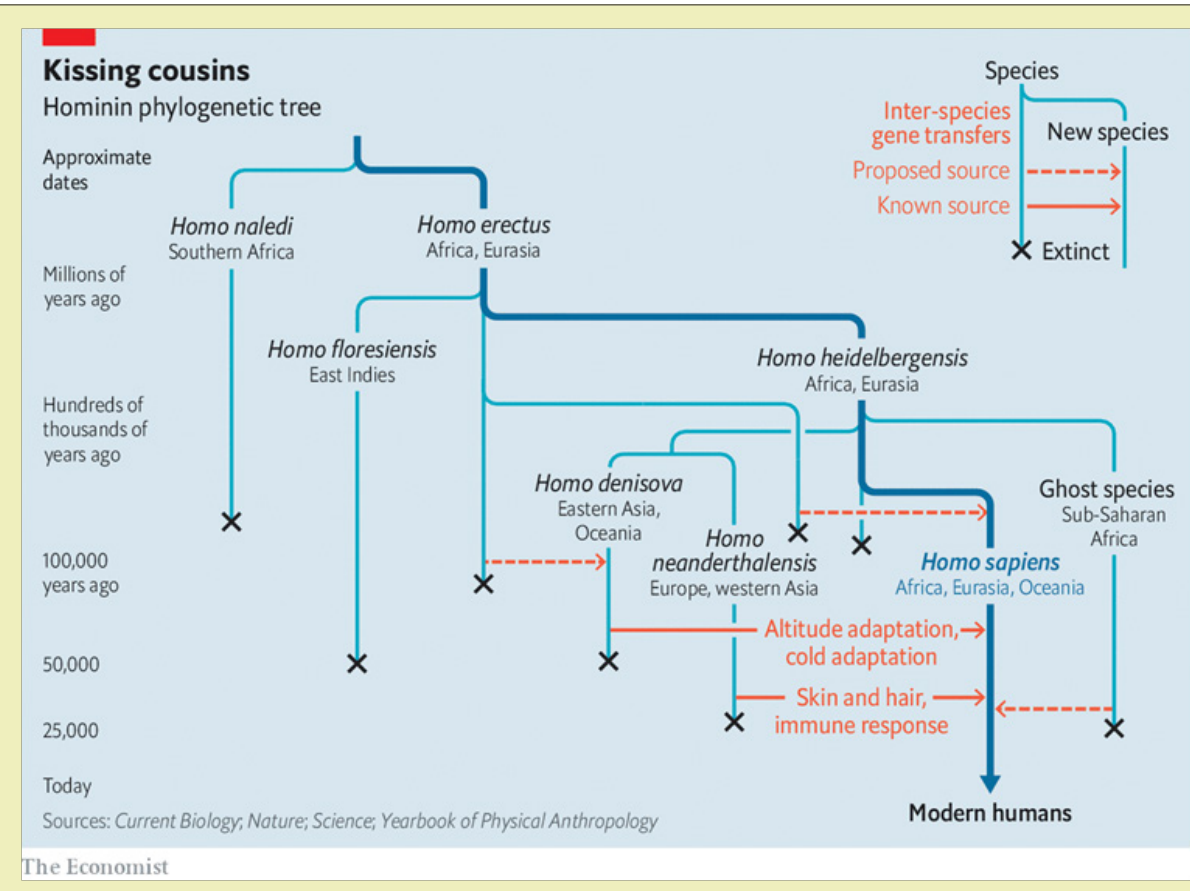

Figure 1: The Economist https://www.economist.com/science-and-technology/2020/10/03/how-hybrids-have-upturned-evolutionary-theory.

Two abilities arose from the stricken Homo Sapiens brain to empower this new creature: imagination and the concept of improvement. Innovation comes from imagination; observations are combined until a new vision forms out of existing patterns. A desire to improve depends on a readiness to be dissatisfied. By criticizing what exists and seeking change restlessness emerges preventing contentment. Homo Sapiens was cast into conflict with everything.

Why humans should be so discontent is a fundamental question because the enchanting beauties in life remain: an attractive person, taste of food, landscapes and natural sounds. The breath-taking view of a snow-capped mountain is the same now as it was millions of years ago. That world into which any creature was born has not changed but to one creature, we it is never good enough. Humans assume a right to assert themselves upon everything. This attitude is a product of our brains. It is more than adapting to our environment and accepting neighbours. All creatures adapt. Beavers build dams to make their fishing easier. Ants construct cities, on their scale, and have demarked social structures as do bees in their hives. Beyond what is needed for survival, they go no further. Humans know no limits.

Where this ambition comes from has to be investigated. Is it inherited as part of the brain cells or is it learned during childhood? No child is aggressive. They are entirely dependent and show traits that may hark back millions of years. A baby's grip is strong. Let them hold your finger. Is that the strength with which they could cling onto a branch when they lived in the trees? Obviously, there are inherited traits so where has the violence come from at which humans excel in a way unmatched by other species.

\section{Communication}

With imagination enabling innovation and a body structure enabling holding tools, weapons were made along with tools for agriculture and building. Communication is said to be unique to humans. In the saved form, writing on clay tablets or data in a micro-chip, human communications are unique but for one individual to communicate with another or many, this is done by many species and often more cleverly. A swooping flock of birds can swirl, rise and descend with all acting as one and without one bumping into another. To our ears, the birds are silent but there is something linking each brain to all the other brains; telepathy on a scale unknown amongst humans. Whales seem to talk to each other miles apart. Elephants have a social structure to protect their herd and raise the young. They do not need to write things down and they have not invented tools, probably because the tools they use are on their head already (trunk and tusks). Without humans, an elephant is safe. Even a tiger will not attack an elephant.

Xenophobia is fear of strangers. For a creature full of curiosity, it is odd that fear of strangers is part of the human attitude. Much of the fear comes from inability to communicate. Language is a barrier and without the telepathic common brain enabling thought sharing which works without language there is also the pragmatic fear of disease transfer. A closed community, think of a remote tribe, develops immunity to the diseases in its territory. An invasion introduces new pathogens to which immunity has not developed and the indigenous population can be wiped out. Co-existence may not be immediately practical. There has to be a time lag allowing antibodies to form. Without communication between the disparate groups, 
animosity prevails with violence. This racism is adopted by individuals who are not at ease in their native community and aimed at the foreigner who is blamed for all their grievances. Groups may have lived within larger groups happily for generations until something changes. It may be technology or political shifts and the minority group finds themselves persecuted. Jews are well aware of this process.

\section{Compulsive Behaviour}

The puzzle of where homo sapiens went wrong may be understood by looking at compulsive behaviour. Every action is behaviour. Some is intentional to further ambitions and some is involuntary. A person feels compelled to do what they are doing and cannot stop themselves. This is addiction and takes many forms, not just swigging alcohol into delirium. By analyzing behaviour from this perspective, we shall try to see where kindness gives way to violence. It should be obvious that kindness is a better basis for relationships between people and their surroundings so why is violence used if it has no benefits and that it has no benefits is certain when wars and killings are looked at in the long term?

My hypothesis on communications is that humans lost the means of sharing brain power when they gained additional skills. Some individuals can read minds claiming to be fortune tellers. They are not able to sense the future but can tell what is in the mind of the respondent giving the impression that they have spiritual powers. Losing the ability to hold information in common with others opens divisions in a community when opinions are discussed. This leads to disagreements, jealousy, xenophobia, violence and war revealing homo sapiens as an inferior species with a brain less well equipped for survival than other species. Although we can make tools, we cannot live without tools.

I watched monkeys in the jungle of India watching me. They had the good sense to know that a human is a predator and would scurry away when I moved. They behaved as one, about fifty of them, able to run up trees as easily as on the ground. A baby hanging to the mother's chest did not impede her climbing skills. They knew their jungle, how to find food and avoid danger. Their society would have leaders and followers with younger leaders ready to usurp weakening elders without the group splitting into warring factions as done by humans. Only by recognising this inadequacy can humans survive and so far, they are failing.

A major cause of human conflict is religion. The question of where we come from and what happens after death arises from a mind that takes nothing for granted but is unable to tolerate groups with different religious views. Students of religious studies explain that the differences are not great and are found in schisms of all branches of religion. The same happens with political views and amongst supporters of sporting teams, especially football. Aided by alcohol, opposing supporters will fight and apparently look forward to the violence following a football match. No similar behaviour is observed in other species. Violence and sport extend to shooting. Birds and animals are killed for entertainment rather than food. The lethal gladiator bouts of ancient Rome are still found, usually without killing, in boxing matches. Humans enjoy violence.
Violence creates violence. If you are under attack, saying soothing things is not a defense. You have to fight back. But what provoked the attacker? Something has gone wrong for that person to resort to violence and finding that fault is the way to bringing violence to an end. We do not need violence even though we are good at it.

\section{The technological common brain}

The time may be right. Just as a flock of birds and a school of fish swirl in harmony, so now can a population looking at their smart phones receive information and be persuaded to act as one. The technology, a product of brains, imagination and ambition, has made up for the deficiencies acquired during a thunderstorm a hundred thousand years ago.

Smart phones should not be used for phone calls held against the ear for more than six minutes. Longer than that causes brain damage. This was found in trials at Bradford University in England. The next version of local, mobile phone networks is $5 \mathrm{G}$ and there is worry that this emits powerful electrical fields that damage our brains.

Artificial communal brains are forming through programmers such as Telegram, WhatsApp, We Chat and many more in all countries that run on smart phones. This technology has spread into all parts of the world and is soon to be able to connect by satellites making the network independent of governments. It will not change brains but it will enable a consensus. Assuming that the majority of people abhor violence and want prosperity, a consensus will not be controversial. By their smart phones, individuals can see what others are saying and thinking and realize that they share the same views. Where they may differ on detail can be pushed to one side in favor of the important objectives of peace, freedom and safety. Freedom does not lead to chaos. As a majority share the same objectives, the result is the majority forming an accord. A minority can see that their opinion need not be drastically different from others and no cause for dissent. We all have preferences as much due to age as anything else (music is where the young and old are usually wide apart) and age differences are spanned by the love transcending generations. The smart phone allows for this. Let granddad listen to his music whilst the teenagers bounce around to theirs. After many thousands of years, our inferior brains with superior technical skills, have made up for what evolution failed to pass down to us. We now have to choose between good and bad applications for technologies.

No other creature has been as stupid as homo sapiens to destroy its habitat. By communicating across the globe, people in one place can see what is being done in another place that affects them even though they cannot visit it. There is now a consensus on the environment. That information is spreading through smart phones just as it would have done from brain to brain if we had not lost the telepathic powers.

A sane person wishes to do no harm. When harm is done, that person is insane and medically ill. At what stage has sanity given way to insanity? How can a normal person go over the top and not 
stop themselves? They are addicted to their actions. They may be ill beyond help but others who have not yet gone over the top could be intercepted and held back from descending the slippery slope (Figure 2).

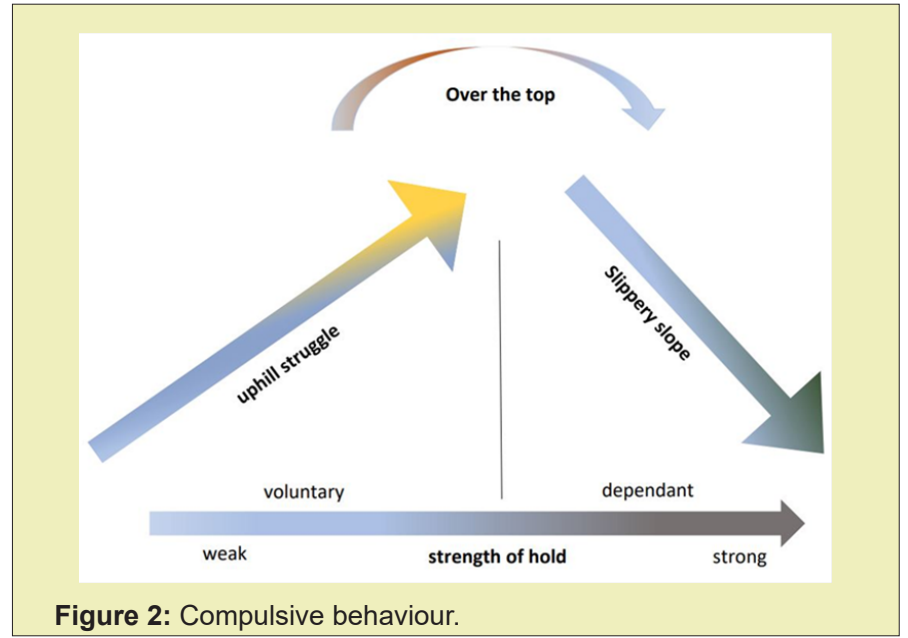

Here is a schematic showing compulsive behaviour. On the left is a weak hold on behaviour. Shift to the right and a person suffers a stronger hold on their actions. They know what they are doing and will want to do it but are unable to stop themselves even when they know they should not do it. On the vertical scale, the schematic shows a rise of benefits which can suddenly lead to tipping over the top and sliding down a slippery slope. The metaphoric description can be graphic when watching a person start taking sports enhancing drugs. Climbing back up the slope is almost impossible. The problem worsens when the self-inflicted victim harms others.

When only the victim is injured, the process can be shrugged off with as much compassion as if that person fell into a flooded river and was drowned but when it leads to millions being killed it is a global disaster. It is more than unfortunate; it is a failure of the brain to use imagination and ambition to create a better life. Now it is up to us to put right was has been going wrong since Homo Sapiens became humans.

\section{Destroying our home}

The destruction of our global environment is well recorded and here is used as an example on the "over the top" diagram designed to show how repeated, stupid behaviour results in disaster (Figure 3 ). Read the diagram from left to right. The world starts with simple camp fires. The heat and carbon dioxide emitted is absorbed by vegetation and oceans with no harm to the environment. Humans find a way to increase their food supply and agriculture develops. This too is within the capacity of the earth but when the industrial revolution gets going based on combustion of carbon the limits of balance are exceeded and carbon dioxide is not absorbed. It collects with other gases in the high atmosphere creating a greenhouse effect which heats the earth and destroys life. Many species will become extinct and, before long, food supplies will dwindle because the crops and animals are not suited to the warmer climate. Storms increase in ferocity leaving homes damaged and costs of repair exceed what the economy can afford. Hopefully, the mistakes made by humans are now recognized and attempts will be made to correct them but whether conditions prior to global warming can be regained or we have to tolerate a permanently hotter world, remains to be experienced. Interestingly, studies of the sun's emissions, for the sun is the source of all energy, show a reduction taking place now which is not apparent because it is overtaken by the human inflicted, atmospheric greenhouse. It is said that by 2050 a global freeze will be upon us.

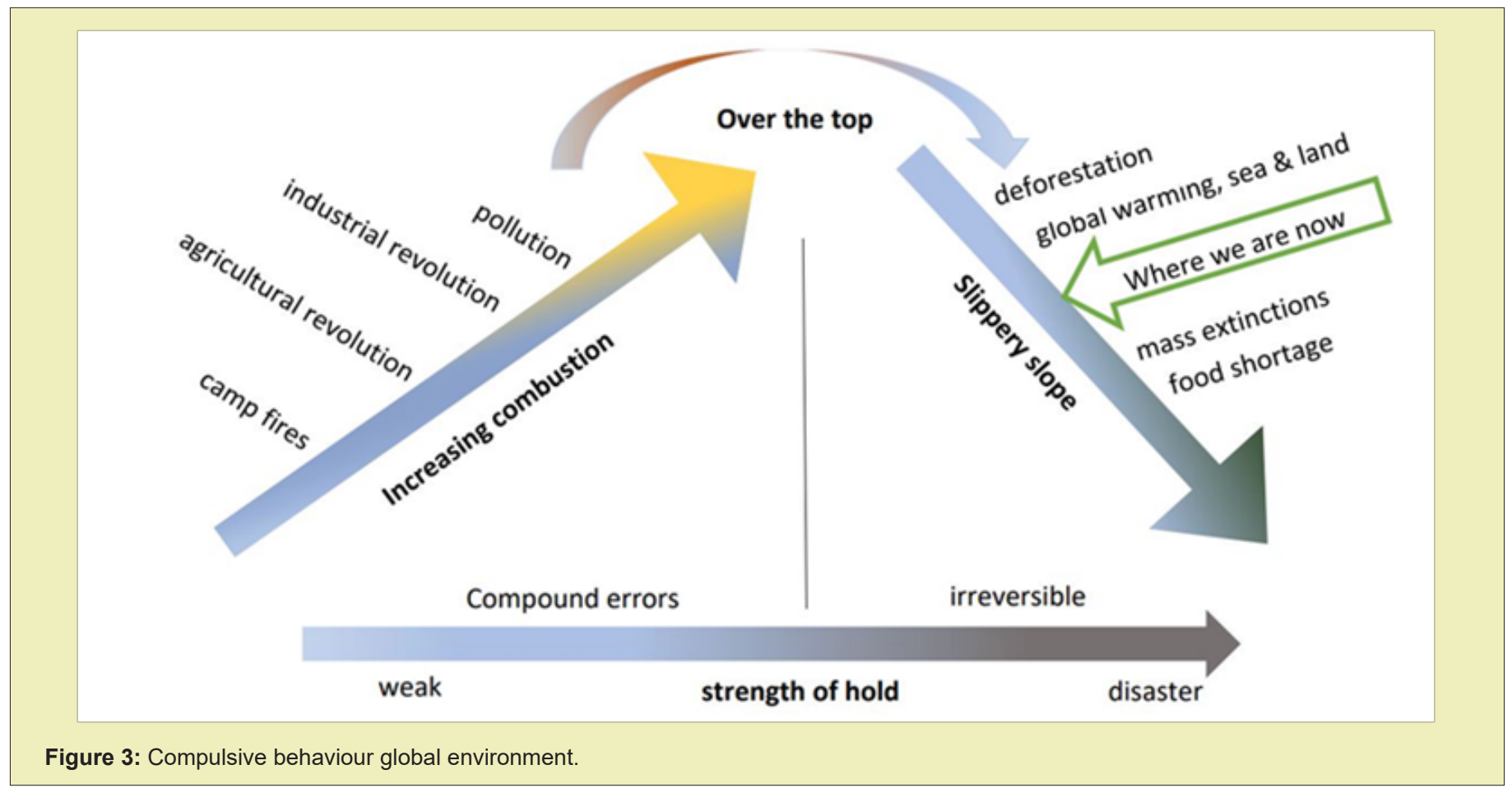




\section{Damaging our Bodies}

Humans hurt themselves before they hurt others, usually. It starts with damage to the body and ends up injuring the brain. The brain and body are so interlinked that healing one involves healing both. Follow the schematic in the diagram above. The lazy person by doing next to nothing is suffering. The body needs exercise as much as it needs food and companionship. The body needs the food and the brain needs the companionship; we are gregarious. Most people will want to move around. When they enjoy exercise, they do more. That's fine until they overdo it. They become committed and addicted to exercise. Usually it is harmless, strengthening their bodies and improving their immune system. It is when they cannot stop themselves that the warning signs appear (Figure 4).

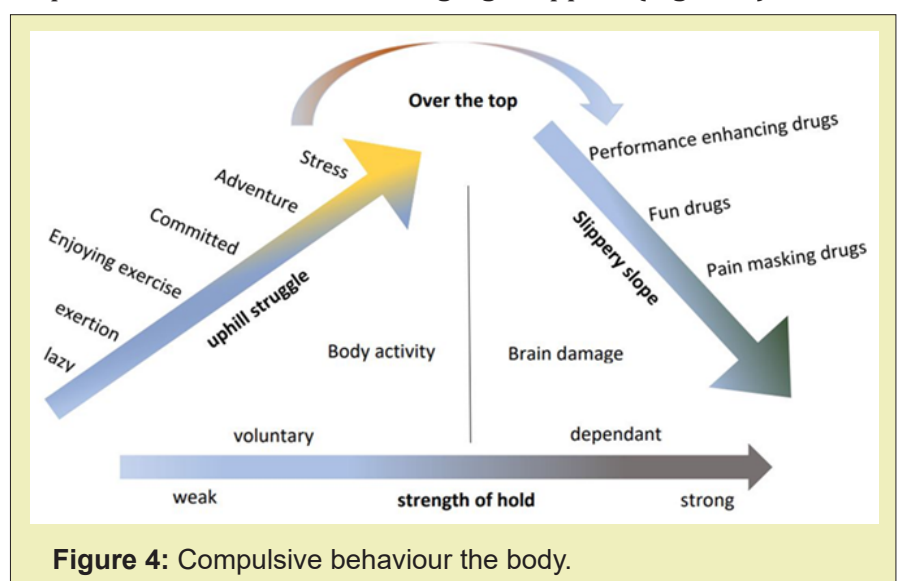

An interesting phenomenon is the adventurer. They insist on doing something difficult, often a stunt, like swimming an ocean or climbing a mountain where no one has been before. They enjoy the physical effort and the publicity. When they lose their sense of danger, they are in trouble. Having survived awful conditions, they go beyond common sense and their luck runs out.

Up to that point, common sense has protected them but that, for them, is too boring and they push the limits. We see this in racing. The way to win a motor race is to go as close to crashing as possible without crashing. When the sport is physical exertion, moving the mental safety controls with drugs allows the person to beat the one unable to ignore the pain barrier. Long distance cycle racing seems to be especially suited to performance enhancing drugs. The longterm consequences are known to all but the immediate reward of winning is all that matters. Dying at fifty or eighty is not a question asked by the 25-year-old with strong legs and little brain. The brain damage can be permanent with the quality of life impaired and a death twenty or more years earlier that it would have been had drugs not been used.

Drugs are blamed. The victim is the fool. There is so much publicity against drugs that there is no excuse for being sucked into temptation. If a person has the will power to force themselves to ride faster than others, have they not the will power to resist temptation? Should a race be about not only finding the strongest rider but also the most stupid and watching them perform to see who dies first? That would be no different to the gladiator tournaments of old when the loser was dragged out by an ox and the winner paraded around on a horse. The competition to find the strongest and fastest is playing to the cruelty in our brains.

\section{Damaging the brain}

Long before industrial processing brought intoxicants to the market, humans had indulged in means of mental escape. They found plants and nuts that could be chewed to make them feel happy or detached. In limited quantities, these drugs may have had little permanent harm (Figure 5).

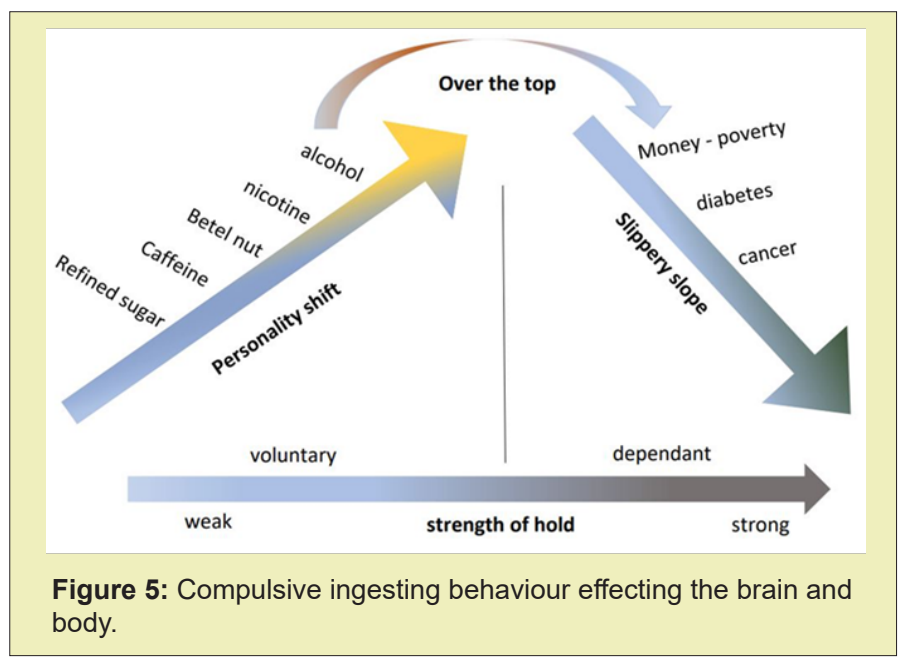

The fact that humans have an appetite for intoxicants reveals the needs of their brain. Industrial production of tobacco, alcohol and narcotics is recent in the time scale of homo-sapiens existence. This confirms that intoxication is normal for this species. It is therefore strange that laws prohibit intoxicants but not food because food is also normal. Laws, generally, are to keep order in society for the benefit of the majority. Whichever way the mind-bending desire of humans is viewed, it is accepted as inevitable and disrupting to society. The individual collides with peers. Is evolution putting the addicted at a disadvantage to reduce their breeding ability and render them extinct?

The addiction diagram above, for that is what it is, shows how involuntary imbibing results in poverty, disease and death. This is obvious to any adult and yet laws are needed to restrain self-harm. Where the damage goes beyond an individual to their family and to the society at large that tries to support the self-inflicted, there is a cost to society.

\section{Masking pain and curing cancer}

Cancer is an electrical fault. Just as the brain is affected by electrical fields so too is all our body. Our cells have a voltage across the cell from inside to outside of-75 mille volts. Cancer cells have a voltage of only - 15 mille volts and this more than anything else distinguishes them from other cells in the body.

We are a new species having developed as recently as a hundred thousand years ago. We inherited a lot from our forebears and changed a lot with a modified brain controlling the body. A fascinating system is in operation to replace all our cells every six weeks 
or so. Each new cell should be an exact copy of the one it replaces and there are billions of cells. With so many, it is likely that the exact replication fails in a few cases. Those failures are identified by our immune system, killed and removed so that we remain healthy. The immune system is a clever diagnostic and healing system run by our brain. With it, we know when we feel not right even though we may not have the words to explain how we feel but we know we have to take corrective action which may be to eat some leaves that grandmother used to tell us about. For most of our existence as a species, that is how we looked after ourselves. Remedies were discovered and passed down the generations. It was when industrial pharmacy took over teaching and regulating medicine and chemistry dominated health management that we departed from traditional methods.

The immune system is disrupted by brain disruption. In most cases, it is stress that prevents the daily, normal interception and elimination of incipient cancer cells. What causes stress, causes cancer. Stress must not be confused with challenge. The adventurer on an expedition is hard at work focused on a project. The body and mind are harnessed to the task and all is well. In contrast, a person feeling overwhelmed and attacked by pressures beyond their control cannot sleep or concentrate. This may be divorce, being sacked, sudden bereavement and all upsets which were not expected and leave the person helpless.

This inability to cope with life is a failure of the brain's operating system. If we had simpler expectations our disappointments would be less but we have a brain that includes ambition. Anyone not trying to improve, learn or progress is criticized as a failure and that criticism can be sufficient to cause stress. Becoming a recluse to escape the pressures of society is impossible because we have a built-in requirement for company; people need people. Cancer is thus, almost inevitable. Statistically a third of the population will get cancer.

Single cancer cells not intercepted and left to replicate are called malignant and form tumors. Their behaviour is different to healthy cells. Chemotherapy aims to kill the cancer cells but being a deadly poison, it usually kills too much and shuts down what is left of the immune system. Radiation causes cancer. The use of chemo and radiation by oncologists is nonsense and contrary to the requirements of the human body.

Cancer is being stopped by non-surgical, irreversible electro oration most notably by using a Cell Sonic VIPP machine to aim at the tumors. The treatment takes a few minutes, the electrical properties of the cells are corrected and then the patient has to be cured of the damage caused by ignorant treatments which invariably are chemotherapy and radiation. I must declare my involvement since I developed the non-surgical procedure about five years ago. My concern now is to advise on avoiding the stresses which damage the immune system which allow cancer to proliferate. A further project at Cell Sonic is developing the diagnostics to measure permittivity so that cancers can be found before a person is aware of it. The time lag between a single cancer cell forming and a patient feeling ill can be ten years and in that time a lot will have gone wrong and full healing becomes difficult because the damage caused by cancer can be extensive.

Our species has the need to replicate cells. We cannot change that. We inherited it and it is how we are. Older species such as ants and sharks have stable organs that do not replicate cells and do not get cancer. Wait another ten million years and we shall have bred the problem out of our system. Until then, we have to accept our frailties and manage them carefully.

Cancer causes pain. Oncologists are generally unable to stop the cancer with their chemo and radiation so the only way to help the patient tolerate pain is to obliterate the brain with a mask cutting off their senses. These masks are drugs. In America, they became common place under the name of opioids. Here are snapshots of the crisis with references to their source (Figures 6-9).

\section{THE OPIOID EPIDEMIC BY THE NUMBERS}
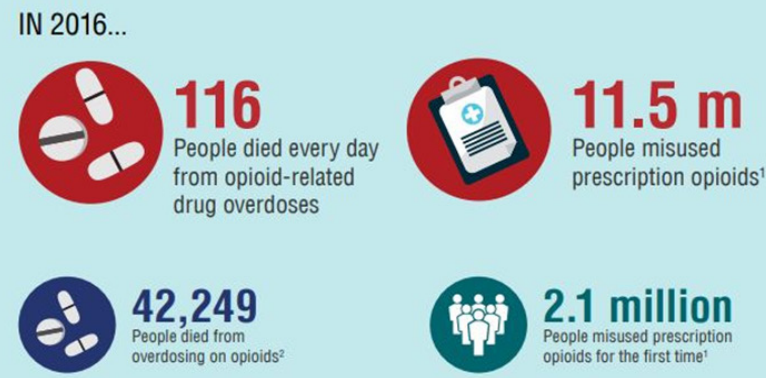

42,249

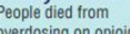

verdosing on opioids ${ }^{2}$
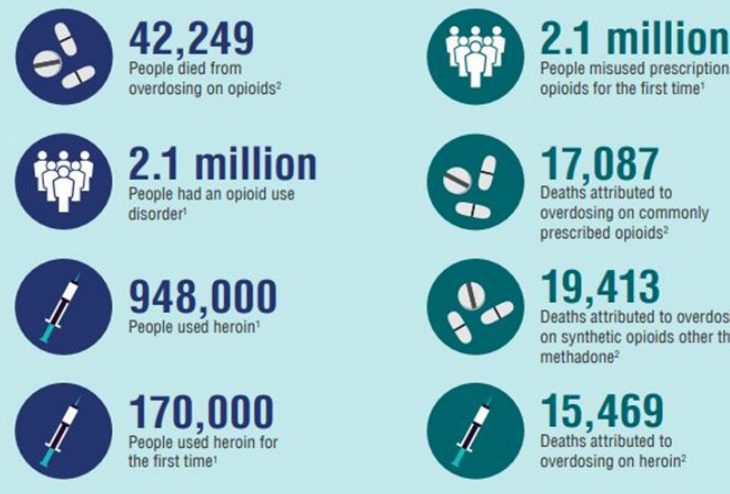

19,413

Deaths attributed to overdosing on synthetic opioids other than

15,469 Deaths attributed to

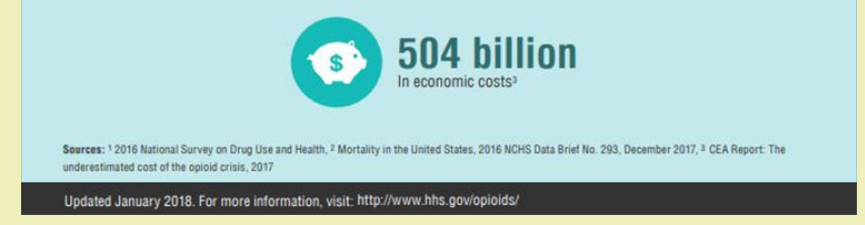

Figure 6: The opioid epidemic by the numbers.

\section{Dangerous characters}

The cost to society becomes enormous when the character of the individual possesses qualities that enable them to influence and exploit others. We see here a process extending into society that is more than self-inflicted harm on an individual. The capacity to inflict suffering and violence combines with other qualities and is a danger to all with no benefits for anyone, least of all the perpetrators (Figure 10). 


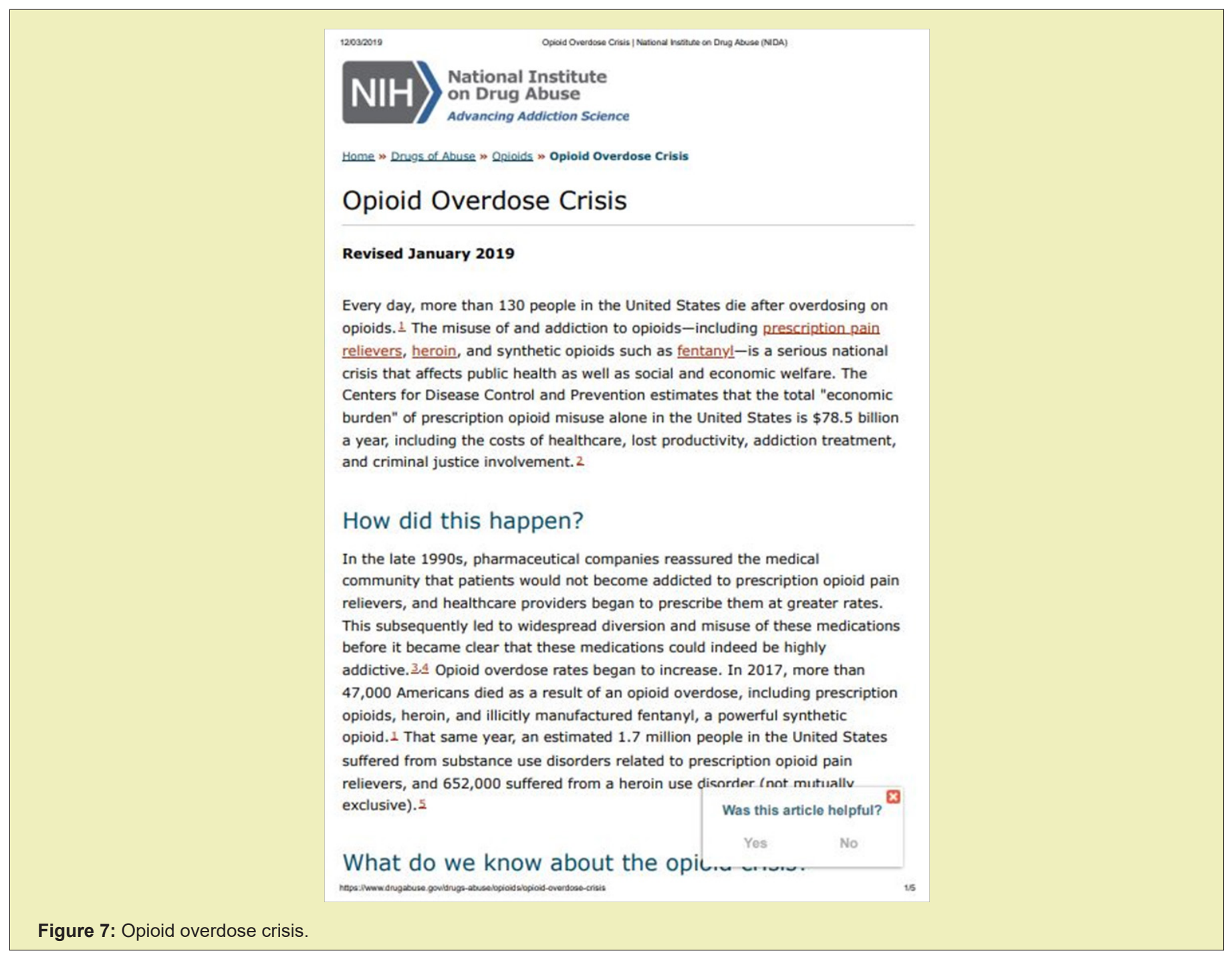

\section{Deadly new heights}

United States, drug overdose deaths

\section{$\overline{100}$}

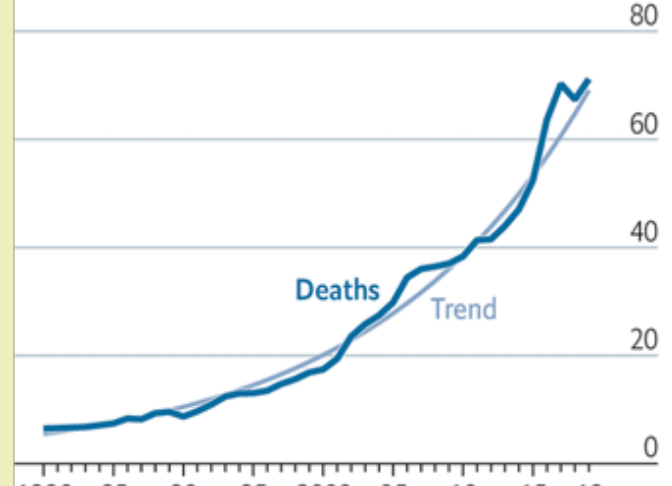

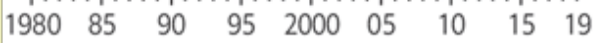

\section{\% change on a year earlier}

60

40

Source: "Carfentanil and the rise and fall of overdose deaths in the United States", by Hawre Jalal and Donald Burke, Addiction, 2020

The Economist

Figure 8: United States drug overdose deaths. 


\title{
Prison time for the opioid crisis
}

\author{
Jan. 24, 2020 1:47 AM ETLAbeut INSYS Therapeutics, Inc. (INSYQ)|By: Yoel Minkoff, SA News Editor \\ Pharma executives linked to the opioid crisis have been put on \\ notice after John Kapoor, the founder of Insys Therapeutics \\ (OTCPK:INSYQ), was sentenced to 66 months in prison.
}

\section{Several other former Insys executives will also end up behind bars for bribing doctors to prescribe the dangerous painkillers.}

While Insys and Purdue Pharma have both gone bankrupt under the weight of legal liabilities, other opioid makers and distributors are trying to negotiate settlement deals with state and local governments.

Figure 9: Prisone time for the opioid crisis.

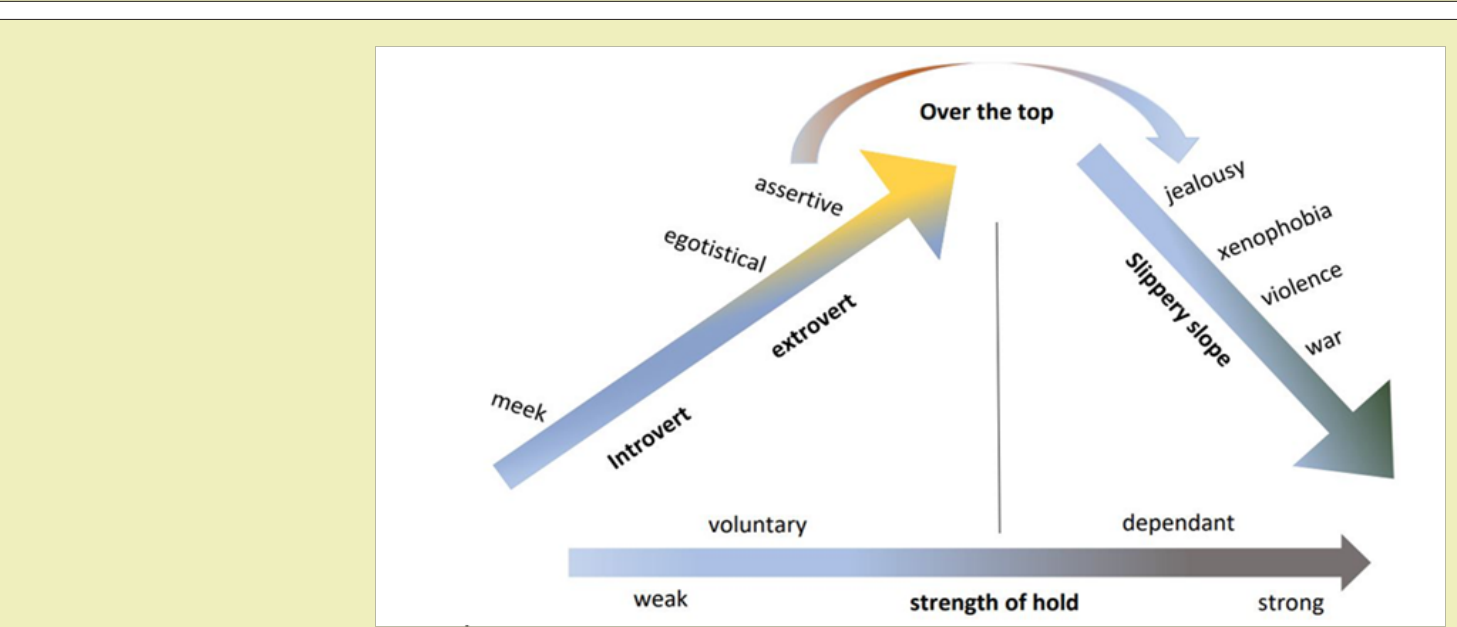

Figure 10: Compulsive behaviour character types.

Today and throughout history we see leaders taking their people into danger on the pretext of going to a better future. After the catastrophe, the survivors have to pick up the pieces and remember to avoid such lies but they never do and the violence reappears again. The individual mind is going along a self-indulgent path of hatred fuelled by jealousy and xenophobia. Followers unthinkingly accept the nonsense and are sucked into the maelstrom. The body is usually the concern of doctors. The fact that the body is controlled by the brain and the brain has inherent problems is ignored by most doctors. Not until brain problems are recognized and dealt with can body illness be healed.

The starting point is to accept that individuals are by and large just that, individuals unconnected to other humans, not even parents and siblings. Seldom are there shared thought patterns which if there were would allow one person to empathies with another. The sense of isolation is as strong as the need for mutual support. Trust is essential and suspicion prevails. After lactation, humans move into a world where they want to love everyone and anyone can be an enemy. Anxiety propels people into illness. The doctor deals with that illness without understanding the root causes. There was nothing in the medical school about brain management and intercepting a person showing characteristics which if left untreated would become dangerous. The warning signs are always there.

The responsibility lies not just with the medical profession but with the whole community. A dictator still needs the acquiescence of the majority. In a democracy, the people should have the sense to see through the candidate's lies. Information is needed and without telepathy we can now get it from hand-held phones. Printed newspapers have reported on wars for the last two centuries. When war photographers submitted pictures of the atrocities, non-combatants began to understand but fighting was still presented by politicians as the way to peace. Suddenly the ubiquitous smart phone has enlightened the view. It is not just a receiver of information; it is a reporter. Videos can be broadcast live from the place of action before anyone invents an excuse. A jury is not needed to assess where the truth lies; the unedited evidence obtained at the scene of action is available to the whole world with everyone a juror. At last, we can form a consensus, something we have not been able to do since a lightning strike deleted the ability from the brain of homo sapiens.

The benefit of mass broadcasting is that there is no political filter. This can be exploited by extremists. Each individual has 
to assess the news, a problem being dealt with by the platforms through which information passes. It is not perfect but better than we used to have. Doctors relish their importance. Now they must recognize their limited education and solve the mental problems, many of which are hidden, alone. There are no professors in the medical schools able to help. Their profession is unable to advise because it does not understand. They deal with addiction and help people through withdrawal but this applies only to intoxicants, not other forms of compulsive behaviour where the end result is violence. Doctors are well placed to identify incipient signs. So too are teachers and relatives. Few of us are able to read the minds of others and we cannot see inside a sealed box. The only clue to what is going on inside is to watch what goes on outside. Crime almost everywhere is ultimately dealt with by punishment and revenge. The stated objective is rehabilitation but in practice that does not happen. The sentence for every criminal should be to be sent to a kind home for love and understanding. Does anyone know how to do this? There was a report from Norway of special prisons run at enormous expense where they were getting close to putting people back to where they were before they came off the track years back, usually in childhood.

\section{References and conclusion}

An academic paper conventionally carries references to other articles from which the author has gathered information. Apart from the diagram of the Hominine phylogenetic tree lifted from The Economist of $3^{\text {rd }}$ October, Match and Mix, page 72, (Current Biology, Nature Science, Yearbook of Physical Anthropology), all the information given is from years of observation by which my opinions have formed. It will be clear that I want a peaceful, loving world and assume everyone wants the same. You will also sense my despair that our innate inadequacies make this almost impossible. Nevertheless, what is difficult may still be achievable and I hope you share my faith in you. Further information about cancer is in http://www. cellsonic-medical.com/. Go to applications and the cancer page. There are many downloads with more information and links to the sources.

\section{Acknowledgments}

None.

\section{Funding}

None.

\section{Conflicts of Interest}

Author declares that there is no conflict of interest. 